\title{
Speciation stability of inorganic polymer flocculant-PACl
}

\author{
Dongsheng Wang ${ }^{\mathrm{a}, *}$, Wei Sun ${ }^{\mathrm{a}}$, Yi Xu ${ }^{\mathrm{a}}$, Hongxiao Tang ${ }^{\mathrm{a}}$, John Gregory ${ }^{\mathrm{b}}$ \\ ${ }^{a}$ SKLEAC, Research Center for Eco-Environmental Science, Academia Sinica, P.O. Box 2871, Beijing 100085, China \\ ${ }^{\mathrm{b}}$ Department of Civil and Environmental Engineering, University College London, Gower Street, London WC1E 6BT, UK
}

Received 27 November 2003; accepted 27 April 2004

\begin{abstract}
The speciation distribution, physico-chemical properties of coagulants, and principles for their further species transformation under various water and wastewater treatment conditions are of paramount importance in coagulation processes. In this paper, the effect of various factors on the speciation transformation of typical inorganic polymer flocculants (IPFs)-polyaluminum chloride (PACl) was investigated by ferron assay. Dilution and co-existing electrolyte exhibit little effect on the speciation distribution of $\mathrm{PACl}$ after dosing. Solution $\mathrm{pH}$ has significant effect on the species transformation, depending mainly on $\mathrm{OH} / \mathrm{Al}$ ratio (denoted as $B$ value). The lower the $B$ value, the more significant the effect $\mathrm{pH}$ exhibits. A large amount of $\mathrm{Al}_{\mathrm{b}}$, i.e. rapid reactive species by ferron assay, could form for alum and $\mathrm{PACl}_{0}$ in the weak acidic $\mathrm{pH}$ range, which transforms quickly into $\mathrm{Al}_{\mathrm{c}}$ after aging. $\mathrm{PACl}$, at high $B$ values, maintains high speciation stability under the various conditions investigated. The ferron method provides a measure to explain the reactivity of different species with ferron. The classification of three kinds of aluminum hydrolysis species based on kinetic differences needs further modification.
\end{abstract}

(C) 2004 Elsevier B.V. All rights reserved.

Keywords: PACl; Speciation stability; Ferron method; Coagulation; Mechanism

\section{Introduction}

Coagulants are one of the key factors in the coagulation process. Alum is the most frequently applied traditional coagulant in the world. Recently, based on conventional iron and aluminum salts, inorganic polymer flocculants (IPFs) have been developed rapidly and become applied widely, especially in China, Japan, Russia, and west Europe [1-5]. Many kinds of IPFs have been developed including aluminum-based, iron-based, inorganic-inorganic composite flocculants, inorganic-organic composite flocculants, and multifunctional composite IPFs [1-8]. Among them, polyaluminum chloride $(\mathrm{PACl})$ is one of the typical kinds and has become most widely applied. The property and general coagulation behavior of IPFs have been extensively investigated [2-5,8-11]. The differences between traditional coagulants and IPFs have been gradually examined. However, previous studies paid most attention to the preparation, characterization, and application of IPFs. Little study has been focused directly on the features of

\footnotetext{
${ }^{*}$ Corresponding author. Fax: +86 1062923543 .

E-mail address: wgds@mail.rcees.ac.cn (D. Wang).
}

chemical speciation during coagulation. There exist few established conclusions as to why their efficiency is superior to the traditional coagulants. It is generally thought that the pre-produced products contain species of superior quality and possess structure fairly stable to further hydrolysis and solution chemistry, resulting in higher coagulation efficiency. The action and mechanism of IPFs are not fully understood.

IPFs are actually clusters or aggregates of a combination of intermediate products with various anions, during hydrolysis of metal salts under suitable conditions. Hence, the study of their aqueous chemistry, especially the species distribution and transformation principles, would build the theoretical basis for IPFs and their further improvement [2]. There are many excellent reviews with large amounts of literature on the aqueous chemistry of $\mathrm{Al}$ (III) and $\mathrm{Fe}$ (III) $[2,12-15]$. However, there exist a few firmly established principles due to the complex nature of hydrolysis. The hydrolysis of $\mathrm{Al}(\mathrm{III})$ follows multiple pathways. A series of hydrolysis species can be formed depending on various factors such as aluminum concentration, sorts of bases adopted, methods of alkalization, speed for base addition, co-existing anions and particles. Therefore, the species formed are 
largely system specific and methodology dependent. Characterization of the different structures and further transformation under various conditions becomes the focus of this field. A number of experimental methods and approaches have been applied. Apart from normal chemical analysis, the analytical methods applied were potential titration, small angle X-ray diffraction, infrared spectroscopy, nuclear magnetic resonance spectroscopy, laser light scattering, small angle X-ray scattering, various electron microscopy, and atomic force microscopy. The timed spectrophotometric method involving reaction of 8-hydroxyquinoline or ferron (8-hydroxy-7-iodo-5-quinoline-sulfonic acid) has also been widely applied to quantify the different species present.

The ferron method was introduced in 1971 as a means of operationally distinguishing between the forms of soluble aluminum in an aqueous system, and it has found wide application in fundamental studies as well as in studies of environmental samples [16-20]. Based on the kinetic difference of the reactions between the aluminum and ferron reagent, the ferron method enables one to partition soluble aluminum species into such categories as monomeric, fast-reacting polymeric, or slow-reacting colloidal species denoted simply as $\mathrm{Al}_{\mathrm{a}}, \mathrm{Al}_{\mathrm{b}}$, and $\mathrm{Al}_{\mathrm{c}}$, respectively. As currently practiced, most previous investigation has focused on the effect of co-existing factors on the kinetic differentiation of aluminum species and possible relationship between $\mathrm{Al}_{\mathrm{b}}$ and $\mathrm{Al}_{13}$ [21]. Studies have also been restricted to soluble species, although mention has been made of the possible reaction between ferron reagent and solid aluminum compounds. Little attention has focused on the kinetic intermediate species formed during preparation, or after dosing in water and wastewater treatment process. Though of paramount importance to the understanding of the mechanism of coagulation, species distribution and transformation after dosing has not been studied sufficiently.

The purpose of this paper is to examine the effect of the various factors involved during coagulation with the typical IPF-PACl, paying special attention to the speciation stability. The effect of dilution, electrolyte concentration, $\mathrm{pH}$, and aging is discussed in detail by using ferron method. The implications for the coagulation mechanism are then discussed.

\section{Materials and methods}

\subsection{Preparation of $\mathrm{PACl}$}

The various $\mathrm{PACl}$ samples were prepared using laboratory alkalinity titration method at room temperature [3]. The reagents used in this study were all of analytical grade except those specifically highlighted. The concentrated stock solution of $2.5 \mathrm{~mol} \mathrm{Al} / \mathrm{L}$ was first prepared by dissolving $\mathrm{AlCl}_{3} \cdot 6 \mathrm{H}_{2} \mathrm{O}$ in distilled water. Prior to the preparation of $\mathrm{PACl}$, a working solution of $0.5 \mathrm{~mol} \mathrm{Al} / \mathrm{L}$ was prepared by diluting the above stock solution in distilled water. A calculated amount of $0.5 \mathrm{~mol} / \mathrm{L} \mathrm{Al}(\mathrm{III})$ solution was then
Table 1

The speciation distribution and $\mathrm{pH}$ value of $\mathrm{PACl}$ samples

\begin{tabular}{llcccl}
\hline No. & $B$ & $\mathrm{Al}_{\mathrm{a}}(\%)$ & $\mathrm{Al}_{\mathrm{b}}(\%)$ & $\mathrm{Al}_{\mathrm{c}}(\%)$ & $\mathrm{pH}$ \\
\hline $\mathrm{PACl}_{0}$ & 0.0 & 91.9 & 8.1 & 0.0 & 3.03 \\
$\mathrm{PACl}_{10}$ & 1.0 & 60.7 & 21.2 & 18.1 & 3.66 \\
$\mathrm{PACl}_{20}$ & 2.0 & 23.6 & 34.5 & 41.9 & 3.94 \\
$\mathrm{PACl}_{25}$ & 2.5 & 7.3 & 40.1 & 52.6 & 5.32 \\
$\mathrm{AS}$ & 0.0 & 87.6 & 12.4 & 0.0 & 3.00 \\
\hline
\end{tabular}

transferred into a $300 \mathrm{~mL}$ jar. Under rapid stirring and bubbling with nitrogen gas, the above solution was titrated slowly with $0.5 \mathrm{~mol} / \mathrm{L} \mathrm{NaOH}$ using a titrometer (665 Dosimat, Metrohm, Switzerland). The amount of $\mathrm{NaOH}$ added varied with the target $\mathrm{OH} / \mathrm{Al}$ ratio (simplified as $B$ values), i.e. $0,1.0,2.0$, and 2.5 , denoted, respectively as $\mathrm{PACl}_{0}$, $\mathrm{PACl}_{10}, \mathrm{PACl}_{20}$, and $\mathrm{PACl}_{25}$. The final concentration of aluminum is $0.1 \mathrm{~mol} / \mathrm{L}$. Meanwhile, $0.1 \mathrm{~mol} \mathrm{Al} / \mathrm{L} \mathrm{Al}_{2}\left(\mathrm{SO}_{4}\right)_{3}$ solution, denoted as AS, was prepared by dissolving alum in distilled water. The samples, after being left to age one week, were analyzed using the ferron method as described below. The results of speciation and $\mathrm{pH}$ measurement are shown in Table 1.

\subsection{Ferron methods}

A slightly modified ferron method was used here. The ferron reagent used by some previous researchers exhibited some unstable features [19,22]. A continuous change in the absorption spectrum of the ferron reagent with aging was observed. Therefore, it has been suggested that different aging times of the mixed ferron solution may be used. The change in the spectrum is thought to be due to reduction of the sulfonate group of ferron to a protonated sulfide group. It can be removed by avoiding the use of hydroxyl ammonium chloride reagent [19]. The main procedure was used as follows.

Reagent A (0.2\% ferron): under rapid stirring, $2 \mathrm{~g}$ ferron (Sigma Chemical Co., MO63178, USA) was dissolved in $1020 \mathrm{~mL}$ distilled water (boiled to remove dissolved $\mathrm{CO}_{2}$ ). Then, filtered and preserved in a $1 \mathrm{~L}$ volumetric bottle.

Reagent B (20\% w/v NaAc): $200 \mathrm{~g} \mathrm{NaAc}$ was dissolved in $1 \mathrm{~L}$ of distilled water.

Reagent C (1:9 v/v HCl): $100 \mathrm{~mL} \mathrm{HCl}(37 \%)$ was mixed with $900 \mathrm{~mL}$ of distilled water.

Prior to the speciation experiments, the mixed ferron solution was obtained by mixing above reagents $\mathrm{A}, \mathrm{B}$, and $\mathrm{C}$ according to a ratio of $2.5: 2: 1$. Then, $5.50 \mathrm{~mL}$ of the mixed reagent was transferred into $25-\mathrm{mL}$ graduated glass tube and diluted to certain volume with distilled water. A certain amount of the sample was then added into the glass tube and quickly diluted to $25 \mathrm{~mL}$. After homogeneous mixing, the reacting sample was quickly added to a $1-\mathrm{cm}$ glass cuvette. The timed absorbance measurements (at $366 \mathrm{~nm}$ ), using a DU650 Beckman UV-Visible spectrophotometer, were carried out after $1 \mathrm{~min}$ and recorded for further $2 \mathrm{~h}$. It was operationally divided that the first $1 \mathrm{~min}$ absorbance as $\mathrm{Al}_{\mathrm{a}}$, and 
1 min to $2 \mathrm{~h}$ as $\mathrm{Al}_{\mathrm{b}}$, then $\mathrm{Al}_{\mathrm{c}}$ was obtained by $\mathrm{Al}_{\mathrm{t}}$ minus $\mathrm{Al}_{\mathrm{a}}$ and $\mathrm{Al}_{\mathrm{b}}$.

To examine the effect of dilution, synthetic water containing $10^{-3} \mathrm{~mol} / \mathrm{L} \mathrm{NaNO}_{3}$ was made up by adding $1 \mathrm{~mol} / \mathrm{L}$ $\mathrm{NaNO}_{3}$ to distilled water. Then, $\mathrm{PACl}$ was added under rapid stirring at $250 \mathrm{rpm}$ for $2 \mathrm{~min}$, followed by slow stirring at $40 \mathrm{rpm}$ for $8 \mathrm{~min}$. The solution was aged for $1 \mathrm{~h}$. The final concentration of the solutions was $5 \times 10^{-4}, 2 \times 10^{-4}$, and $5 \times 10^{-5} \mathrm{~mol} \mathrm{Al} / \mathrm{L}$, respectively. After $2 \mathrm{~min}$ and $1 \mathrm{~h}$ aging, the solution was analyzed subsequently by ferron assay.

During the examination of the effect of $\mathrm{pH}$, the same procedure was applied except that the synthetic water contained respectively $5 \times 10^{-4} \mathrm{~mol} / \mathrm{L} \mathrm{NaHCO}_{3}$ and $\mathrm{NaNO}_{3}$ in distilled water. A pre-determined amount of 0.2 or $0.05 \mathrm{~mol} / \mathrm{L}$ $\mathrm{NaOH}$ or $\mathrm{HCl}$ solution was used and added first into the synthetic water to control the final $\mathrm{pH}$. Under rapid stirring at $250 \mathrm{rpm}$, a certain amount of coagulants were then dosed. The final concentration of the solutions was $2 \times 10^{-4}$, $1 \times 10^{-4}, 8 \times 10^{-5}$, and $5 \times 10^{-5} \mathrm{~mol} \mathrm{Al} / \mathrm{L}$, respectively (to examine the effect of dosage also). After $2 \mathrm{~min}$ and $1 \mathrm{~h}$ aging, the solution was subsequently analyzed by ferron assay.

\section{Results and discussion}

\subsection{Effect of dilution and ionic strength}

To examine the effect of dilution, the coagulants were dosed directly into distilled water containing $10^{-3} \mathrm{~mol} / \mathrm{L}$ $\mathrm{NaNO}_{3}$. The final concentration of solutions was $5 \times 10^{-4}$, $2 \times 10^{-4}$, and $5 \times 10^{-5} \mathrm{~mol} \mathrm{Al} / \mathrm{L}$, respectively. After aging for $2 \mathrm{~min}$ and $1 \mathrm{~h}$ respectively, the solution was subsequently analyzed by ferron assay. The results at dosage of $2 \times 10^{-4} \mathrm{~mol}$ $\mathrm{Al} / \mathrm{L}$ are summarized in Table 2 . The original concentration of species distribution for the coagulants is also shown for comparison. It can be seen that dilution has little effect on the speciation distribution of PACls after dosing. Similar results are observed for the other dosages investigated in the range of dilution factors of 200-2000 times. Speciation distribution

Table 2

The speciation distribution and $\mathrm{pH}$ value of $\mathrm{PACl}$ samples

\begin{tabular}{lllllll}
\hline No. & $B$ & Time & $\mathrm{Al}_{\mathrm{a}}(\%)$ & $\mathrm{Al}_{\mathrm{b}}(\%)$ & $\mathrm{Al}_{\mathrm{c}}(\%)$ & $\mathrm{pH}$ \\
\hline $\mathrm{PACl}_{0}$ & 0.0 & 0 & 91.9 & 8.1 & 0.0 & 3.03 \\
& & $2 \mathrm{~min}$ & 93.6 & 6.4 & 0.0 & 4.34 \\
& & $1 \mathrm{~h}$ & 94.8 & 5.2 & 0.0 & 4.32 \\
$\mathrm{PACl}_{10}$ & 1.0 & 0 & 60.7 & 21.2 & 18.1 & 3.66 \\
& & $2 \mathrm{~min}$ & 61.5 & 20.0 & 18.5 & 4.64 \\
& & $1 \mathrm{~h}$ & 61.3 & 21.1 & 17.6 & 4.61 \\
$\mathrm{PACl}_{20}$ & 2.0 & 0 & 23.6 & 34.5 & 41.9 & 3.94 \\
& & $2 \mathrm{~min}$ & 23.8 & 34.9 & 41.3 & 4.89 \\
& & $1 \mathrm{~h}$ & 24.2 & 34.2 & 41.6 & 4.88 \\
$\mathrm{PACl}_{25}$ & 2.5 & 0 & 7.3 & 40.1 & 52.6 & 5.32 \\
& & $2 \mathrm{~min}$ & 6.9 & 44.6 & 49.5 & 5.32 \\
& & $1 \mathrm{~h}$ & 7.5 & 42.1 & 50.4 & 5.34 \\
\hline
\end{tabular}

shows little alteration, especially for the high $B$ value PACls.

The $\mathrm{pH}$ recorded for the original $\mathrm{PACl}_{0}, \mathrm{PACl}_{10}, \mathrm{PACl}_{20}$, and $\mathrm{PACl}_{25}$ solution is 3.03, 3.66, 3.94, and 5.32, respectively. Considering the effect of spontaneous hydrolysis with the enhanced hydrolysis by alkalinity addition, the hydrolyticity for $\mathrm{Al}(\mathrm{III})$, i.e. $B^{*}\left(B^{*}=B_{\mathrm{H}}+B-A\right.$, see text of Tang and Stumm [1], in detail), could be calculated by using the method proposed previously. The $B$ value equates to $\mathrm{OH}_{\mathrm{add}} / \mathrm{Al}_{\mathrm{T}} . B_{\mathrm{H}}$ is obtained from the spontaneous hydrolysis $(\mathrm{SH})$ of $\mathrm{Al}(\mathrm{III})$, i.e. $\mathrm{OH}_{\mathrm{SH}} / \mathrm{Al}_{\mathrm{T}}$, while the $A$ value equals the acid added, i.e. $\mathrm{H}_{\mathrm{add}} / \mathrm{Al}_{\mathrm{T}}$. Here, no acid has been added during the preparation of PACls, therefore, $A=0$. The $B^{*}$ values calculated, considering the spontaneous effect of hydrolysis, are $0.009,1.003,2.001$, and 2.500, respectively, for the original $\mathrm{PACl}_{0}, \mathrm{PACl}_{10}, \mathrm{PACl}_{20}$, and $\mathrm{PACl}_{25}$ solutions. Obviously, there is no significant difference between $B$ and $B^{*}$ in the original solutions.

However, a weak alkalization can be expected during dilution as the $\mathrm{pH}$ of solution is raised. Considering the case of final concentration of $2 \times 10^{-4} \mathrm{~mol} \mathrm{Al} / \mathrm{L}$, the solution $\mathrm{pH}$ of $\mathrm{PACl}_{0}, \mathrm{PACl}_{10}, \mathrm{PACl}_{20}$, and $\mathrm{PACl}_{25}$ becomes 4.34, 4.64, 4.89 , and 5.32, respectively, after dosing. The calculated $B^{*}$ values then are $0.239,1.115,2.065$, and 2.524 , respectively. Although a significant increase of $B^{*}$ value occurs for the low $\mathrm{OH} / \mathrm{Al}$ ratio PACls, no evident alteration of the species distribution is observed, as shown in Table 2. It is indicative that the change of $B^{*}$ corresponds mainly with the change of charge of the species, e.g. from $\mathrm{Al}(\mathrm{OH})^{2+}$ to $\mathrm{Al}(\mathrm{OH})_{2}{ }^{+}$ and $\mathrm{Al}_{13}{ }^{7+}$ to $\mathrm{Al}_{13}{ }^{5+}$. Therefore, no species transformations along categories of $\mathrm{Al}_{\mathrm{a}}, \mathrm{Al}_{\mathrm{b}}$, and $\mathrm{Al}_{\mathrm{c}}$ take place, while the charge of the species decreases as $B^{*}$ increases. Additional sets of experiments were also carried out to examine the effect of concentration of electrolyte on the speciation of PACls after dosing. The range of concentration of $\mathrm{NaNO}_{3}$ examined was $10^{-4}$ to $0.1 \mathrm{~mol} / \mathrm{L}$. Results show that the concentration of $\mathrm{NaNO}_{3}$ examined has little effect on the speciation distribution of the primary coagulants.

\subsection{Effect of $p H$ on the speciation transformation of $\mathrm{PACl}$ after dosing}

During the examination of the effect of $\mathrm{pH}$, synthetic water containing respectively $5 \times 10^{-4} \mathrm{~mol} / \mathrm{L} \mathrm{NaHCO}_{3}$ and $\mathrm{NaNO}_{3}$ in deionized water was used. A pre-determined amount of 0.2 or $0.05 \mathrm{~mol} / \mathrm{L} \mathrm{NaOH}$ or $\mathrm{HCl}$ solution was used and added first into the synthetic water to control the final target $\mathrm{pH}$. The speciation analysis was then carried out after coagulants were dosed. The results of speciation characterization at a $\mathrm{PACl}$ dose of $2 \times 10^{-4} \mathrm{~mol} \mathrm{Al} / \mathrm{L}$ are summarized in Fig. 1. It can be seen that $\mathrm{pH}$ has a significant effect on further speciation transformation of $\mathrm{PACl}$, corresponding with $\mathrm{OH} / \mathrm{Al}$ values. For $\mathrm{PACl}_{0}$ and $\mathrm{AS}$, i.e. $\mathrm{OH} / \mathrm{Al}=0$, in the acidic region, $\mathrm{Al}_{\mathrm{a}}$ decreases rapidly as $\mathrm{pH}$ is raised, and reaches a minimum in the near neutral $\mathrm{pH}$ region. Upon increase of $\mathrm{pH}$ to the alkaline portion of 

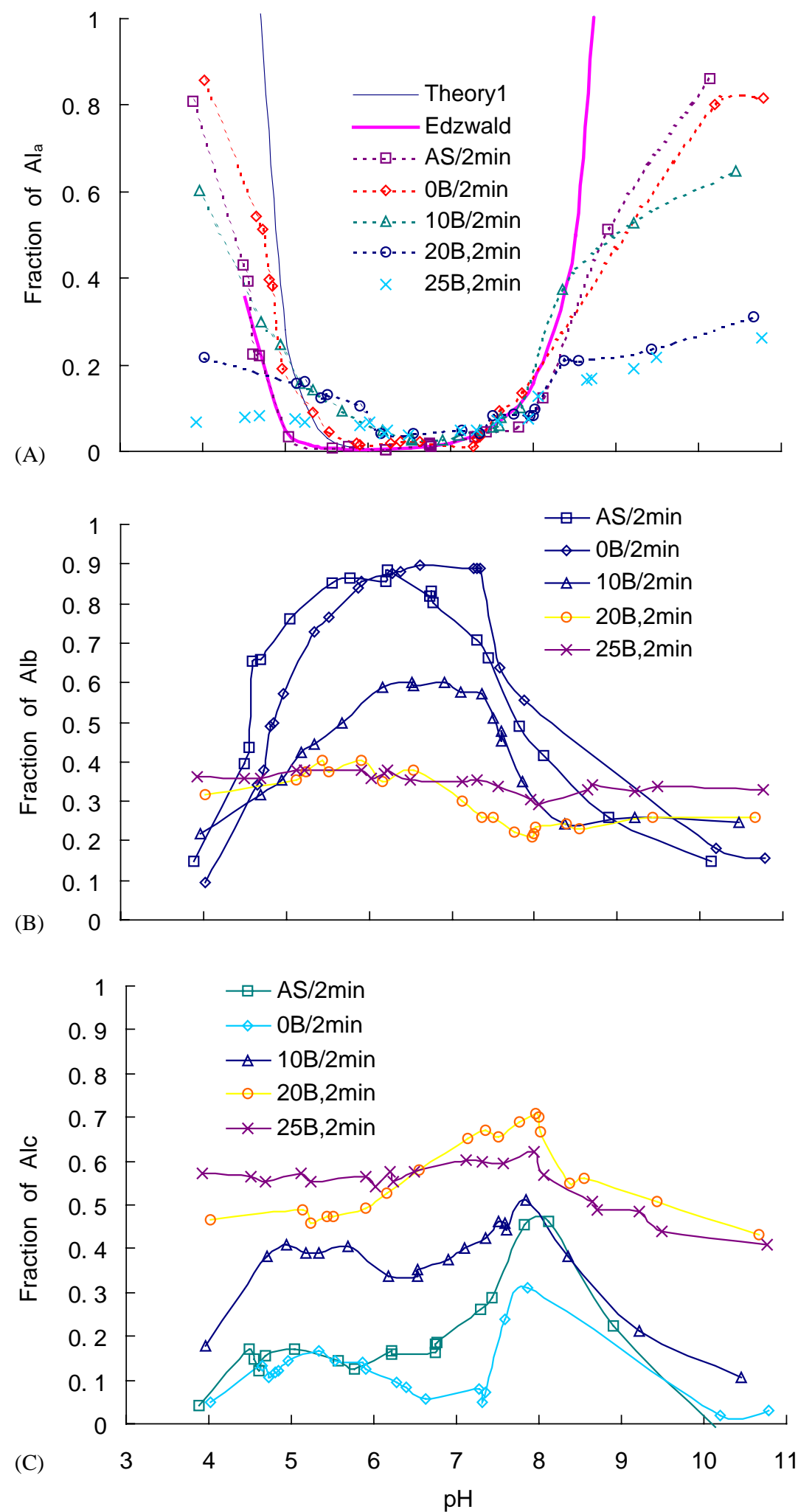

Fig. 1. The speciation characterization after dosing of $\mathrm{PACl}$ under various $\mathrm{pH}$ conditions at constant dosage of $2 \times 10^{-4} \mathrm{~mol} \mathrm{Al}^{\prime} / \mathrm{L}$ : (A) $\mathrm{Al}_{\mathrm{a}}$; $(\mathrm{B}) \mathrm{Al}_{\mathrm{b}}$; (C) $\mathrm{Al}_{\mathrm{c}}$. (For interpretation of the references to color in this figure legend, the reader is referred to the web version of the article.) 
the figure, the $\mathrm{Al}_{\mathrm{a}}$ species increases sharply again. In contrast, a rapid increase of the $\mathrm{Al}_{\mathrm{b}}$ species can be observed in the acidic $\mathrm{pH}$ region. The maximum of $\mathrm{Al}_{\mathrm{b}}$ occurs in the near neutral $\mathrm{pH}$ conditions. In the alkaline portion, a rapid decrease occurs as $\mathrm{pH}$ is raised. The distribution of $\mathrm{Al}_{\mathrm{c}}$ is similar to that of $\mathrm{Al}_{\mathrm{b}}$, but the scale of change is smaller.

Similar trends of the change in $\mathrm{Al}_{\mathrm{a}}, \mathrm{Al}_{\mathrm{b}}$, and $\mathrm{Al}_{\mathrm{c}}$ species are also observable for the other PACls at higher $\mathrm{OH} / \mathrm{Al}$ ratio. However, the scale of change largely decreases with increasing $\mathrm{OH} / \mathrm{Al}$. For $\mathrm{PACl}_{10}$, the decrease of $\mathrm{Al}_{\mathrm{a}}$ with large yield of $\mathrm{Al}_{\mathrm{b}}$ occurs obviously in the weak acidic conditions. Increasing $\mathrm{OH} / \mathrm{Al}$ ratio to 2.0 , i.e. $\mathrm{PACl}_{20}$, the trend becomes less observable. Note that the decrease of $\mathrm{Al}_{\mathrm{a}}$ is not so significant, as the original fraction of $\mathrm{Al}_{\mathrm{a}}$ in $\mathrm{PACl}_{10}$ is only $61 \%$ prior to dosing. While for $\mathrm{PACl}_{25}$, there is not much difference of the speciation distribution throughout the $\mathrm{pH}$ range investigated.

Obviously, further transformation of PACls species after dosing under the various conditions depends largely on the original composition. The PACls at low $\mathrm{OH} / \mathrm{Al}$ ratio show a significant change of species under the various conditions. The high $\mathrm{OH} / \mathrm{Al}$ ratio PACls exhibit efficient speciation stability and tend to maintain the original speciation distribution. As shown in Table 1, the $\mathrm{PACl}_{0}$ and AS contain mainly $\mathrm{Al}_{\mathrm{a}}$ monomers. After dosing in water, this species undergoes dramatic change as shown in Fig. 1. In the $\mathrm{pH}$ range 5.5-6.5, the $\mathrm{Al}_{\mathrm{a}}$ species transforms largely to $\mathrm{Al}_{\mathrm{b}}$ with fractions reaching $80-90 \%$, plus $10-20 \%$ of $\mathrm{Al}_{\mathrm{c}}$. Above $\mathrm{pH} 7.0$, a significant amount of $\mathrm{Al}_{\mathrm{b}}$ changes further into $\mathrm{Al}_{\mathrm{c}}$. $\mathrm{As} \mathrm{OH} / \mathrm{Al}$ ratio increases, the quantity of $\mathrm{Al}_{\mathrm{a}}$ in the primary coagulants decreases quickly, with large increase of $\mathrm{Al}_{b}$ and finally $\mathrm{Al}_{\mathrm{c}}$. For $\mathrm{PACl}_{10}$, the $\mathrm{Al}_{\mathrm{a}}$ species remains the main component, $60 \%$, with $22 \%$ of $\mathrm{Al}_{\mathrm{b}}$ and $18 \%$ of $\mathrm{Al}_{\mathrm{c}}$. As shown in Fig. 1, that maximum $\mathrm{Al}_{\mathrm{b}}$ fractions is $60 \%$ with $40 \% \mathrm{Al}_{\mathrm{c}}$. In comparison with the primary composition in $\mathrm{PACl}_{10}$, it can be estimated that the original $60 \%$ of $\mathrm{Al}_{\mathrm{a}}$ equates roughly to $40 \%$ of $\mathrm{Al}_{\mathrm{b}}$ and $20 \%$ of $\mathrm{Al}_{\mathrm{c}}$. It is indicative that the $\mathrm{Al}_{\mathrm{a}}$ constituent in $\mathrm{PACl}_{10}$ exhibits a similar change to that in $\mathrm{PACl}_{0}$. Similar results are seen for $\mathrm{PACl}_{20}$, while for $\mathrm{PACl}_{25}$, there is a minor quantity of $\mathrm{Al}_{\mathrm{a}}(8 \%)$. The distribution of $\mathrm{Al}_{\mathrm{a}}, \mathrm{Al}_{\mathrm{b}}$, and $\mathrm{Al}_{\mathrm{c}}$ remains almost the same throughout the $\mathrm{pH}$ range investigated. The results shown above indicate that the $\mathrm{Al}_{\mathrm{a}}$ fraction in the primary coagulants contains the most labile species. After dosing, these species would quickly transform into $\mathrm{Al}_{\mathrm{b}}$, and finally $\mathrm{Al}_{\mathrm{c}}$ depending on the reaction conditions. The polymeric and colloidal species, once preformed, are quite stable. In addition, the $\mathrm{Al}_{\mathrm{b}}$ and $\mathrm{Al}_{\mathrm{c}}$ species formed after dosing exhibit a quite different nature to the preformed species, as will be addressed in further detail later.

A comparison of the above results with the solubility diagram of $\mathrm{Al}(\mathrm{III})$ provides further insight to the principle of speciation transformation after dosing. Normally, the solubility diagram or a more comprehensive stability-coagulation diagram can be used to illustrate the behavior of the traditional coagulants, as suggested first by Amirtharajah and co-workers [23,24]. It is constructed using the equilibrium constant from comprehensive compilation and collation of data from coagulation experiments. Such a diagram can be used to predict the relationship between concentration of aluminum $(\mathrm{pC})$ and $\mathrm{pH}$, addressing to some extent the coagulation mechanism. However, the choice of reaction schemes of possible species can often be arbitrary. The amorphous $\mathrm{Al}(\mathrm{OH})_{3}(\mathrm{~s})$ has normally been chosen as the controlling solid phase, while other investigations favored the more crystalline phase. Considering the probable existence of polymer species, either formed in solution or possibly adsorbed onto surfaces, much more complicated cases may be expected. In practice, some reactions are system specific. Furthermore, the kinetic aspect of aggregation is not included in the diagram. When coagulants are added, the solution is not highly supersaturated to the solubility limit and therefore is often metastable. The precipitation formation is kinetically slow and the solid phase may not form. In addition, the diagram is largely restricted to the traditional metal salts. Thus, the application to preformed $\mathrm{PACl}$ is limited. The solubility scheme based on the equilibrium with amorphous aluminum hydroxide can no longer be valid for the species being tailor-made. Although the coagulation diagram can be used to roughly differentiate between the state of coagulation-flocculation by full application of the available research results, this remains to be tested by experimental results. A quantitative calculation could not be reached.

Fig. 1A also includes the theoretically calculated solubility (the thin solid line and dotted line) and the experimental results of Van Benschoten and Edzwald (the thick solid line) [11]. The alum dose used by Van Benschoten and Edzwald was $1 \times 10^{-4} \mathrm{~mol} / \mathrm{L}$, which equates to $50 \%$ of the dose adopted in this investigation $\left(2 \times 10^{-4} \mathrm{~mol} / \mathrm{L}\right)$. The soluble species used in constructing the curve in Fig. $1 \mathrm{~A}$ were $\mathrm{Al}^{3+}$, $\mathrm{Al}(\mathrm{OH})^{2+}$, and $\mathrm{Al}(\mathrm{OH})_{4}^{-}$(for the thin solid line). The dotted line is the theoretical solubility of $\mathrm{Al}$ including the fourth monomer, $\mathrm{Al}(\mathrm{OH})_{2}{ }^{+}$. Amorphous $\mathrm{Al}(\mathrm{OH})_{3}$ is assumed to be the solid phase controlling solubility. Al hydrolysis constants are shown in Table 3. A temperature of $25^{\circ} \mathrm{C}$ was used in the calculations. It can be seen that the experimental results of AS (alum) fit well to those of Van Benschoten and Edzwald. Note that the results obtained by Van Benschoten and Edzwald were carried out on the filtered samples, while the data in this study were determined directly as the $\mathrm{Al}_{\mathrm{a}}$

Table 3

Aluminum hydrolysis constants

\begin{tabular}{lll}
\hline Reaction & $\mathrm{p} K$ & Reference \\
\hline $\mathrm{Al}^{3+}+\mathrm{SO}_{4}^{2-}=\mathrm{AlSO}_{4}^{+}$ & $\mathrm{p} K_{\text {sulf }}=3.50$ & {$[12]$} \\
$\mathrm{Al}^{3+}+\mathrm{H}_{2} \mathrm{O}=\mathrm{Al}(\mathrm{OH})^{2+}+\mathrm{H}^{+}$ & $\mathrm{p} K_{11}=4.99$ & {$[12]$} \\
$\mathrm{Al}^{3+}+\mathrm{H}_{2} \mathrm{O}=\mathrm{Al}(\mathrm{OH})_{2}++2 \mathrm{H}^{+}$ & $\mathrm{p} K_{12}=10.1$ & {$[12]$} \\
$\mathrm{Al}^{3+}+\mathrm{H}_{2} \mathrm{O}=\mathrm{Al}(\mathrm{OH})_{4}{ }^{-}+4 \mathrm{H}^{+}$ & $\mathrm{p} K_{14}=23.0$ & {$[12]$} \\
$\mathrm{Al}^{3+}+3 \mathrm{OH}=\mathrm{Al}^{-}(\mathrm{OH})_{3}(\mathrm{~s})$ & $\mathrm{p} K_{\text {so }}=31.6$ & {$[12]$} \\
$\mathrm{Al}^{3+}+\mathrm{H}_{2} \mathrm{O}+\mathrm{SO}_{4}^{2-}$ & $\mathrm{p} K_{\text {so } / \text { sulf }}=35.2$ & - \\
$\quad=\mathrm{Al}(\mathrm{OH})_{3-2 x}\left(\mathrm{SO}_{4}\right)_{x}(\mathrm{~s})$ & & \\
\hline
\end{tabular}


fraction. This indicates that the $\mathrm{Al}_{\mathrm{b}} / \mathrm{Al}_{\mathrm{c}}$ fractions might be involved in the particle form, although no attempt has been made to characterize particle size evolution features after dosing.

A significant difference between the alum and PACls can also be observed. The experimental data for alum appear to show slightly more insolublility than the theoretical curve, and the curve for PACls. As shown in Fig. 1A, a systematic move of the curve to low $\mathrm{pH}$ region can be observed for alum versus the other PACls in the acidic region. The data near $\mathrm{pH} 4$ are undersaturated with respect to the solid phase, but the remaining data between $\mathrm{pH} 4.5$ and 6.5 indicate more insoluble solid phase than in theoretical predictions. These data exhibit the significant effect of the sulfate. The precipitate is easily formed in the presence of sulfate, therefore, the solubility diagram moves to the low $\mathrm{pH}$ range. This has been shown in the coagulation experiments carried out previously [3]. Meanwhile, although sulfate complexes moderately with $\mathrm{Al}(\mathrm{III})$ species [25], it is reasonable to consider the solubility controlling solid phase in the acidic $\mathrm{pH}$ range as amorphous $\mathrm{Al}(\mathrm{OH})_{3-2 x}\left(\mathrm{SO}_{4}\right)_{x}(0<x<2.5)$. The corresponding value of the formation constants could be inferred by comprehensively combining reactions 1 and 4. A regression line in the $\mathrm{pH} 5-6$ range gave a slope $=-2.4$ and a $\log \mathrm{K}_{\mathrm{so} / \text { sulf }}=-35.2$, as indicated also by Van Benschoten and Edzwald [11]. Considerable evidence suggests that $\mathrm{Al}$ solubility in the acidic $\mathrm{pH}$ range may be controlled by an $\mathrm{Al}-\mathrm{SO}_{4}$ precipitate [26,27], although other investigators [28] disfavor such findings.

Comparison of $\mathrm{Al}_{\mathrm{a}}$ fractions of $\mathrm{PACl}$ to the $\mathrm{Al}$ solubility curve gives some interesting features. It was shown from Fig. $1 \mathrm{~A}$ that the $\mathrm{Al}_{\mathrm{a}}$ fractions of PACls correspond well to the dotted theoretical Al solubility curve. This is indicative that $\mathrm{Al}_{\mathrm{a}}$ fractions follow well the control of solubility limit. The $\mathrm{Al}_{\mathrm{b}} / \mathrm{Al}_{\mathrm{c}}$ species are the metastable species, which would transform finally into precipitates. The results indicate further that the involvement of $\mathrm{Al}(\mathrm{OH})_{2}{ }^{+}$monomer is a reasonable hypothesis, although some investigators question the validity of the reaction constant of $\mathrm{Al}(\mathrm{OH})_{2}{ }^{+}$. No alteration of the amount of $\mathrm{Al}_{\mathrm{a}}, \mathrm{Al}_{\mathrm{b}}$, and $\mathrm{Al}_{\mathrm{c}}$ occurs by simply changing $\mathrm{Al}(\mathrm{OH})^{2+}$ to $\mathrm{Al}(\mathrm{OH})_{2}{ }^{+}$as solution $\mathrm{pH}$ is raised. The difference of the analysis from Van Benschoten and Edzwald might be explained by the remarkable effect of the sulfate ion. It can also be seen from Fig. 1A that the solubility of $\mathrm{PACl}_{20}$ and $\mathrm{PACl}_{25}$ is slightly increased in the acidic region. The data points near $\mathrm{pH} 4$ are undersaturated with respect to the solid phase. The smaller the $\mathrm{Al}_{\mathrm{a}}$ fractions in the primary PACls, the more the effect of undersaturation is evident. However, in the $\mathrm{pH} 5.0-6.5$ range, a slight increase of solubility for $\mathrm{PACl}$ with increasing $\mathrm{OH} / \mathrm{Al}$ ratio indicates different solubility controlling solid phases. For $\mathrm{PACl}_{0}$, amorphous $\mathrm{Al}$ hydroxide with large surface area may be formed as evidenced from the different reactivity with ferron. Precipitate formation is far away from the stable state. Upon further aging, part of the adsorbed species becomes dissolved and the structure re-arranges, resulting in the increased solubility. For the PACls at high $\mathrm{OH} / \mathrm{Al}$ ratio, the polymer species are quite stable. A metastable solution is formed.

If the species fraction diagram is arbitrarily divided at the point of onset of rapid decrease of $\mathrm{Al}_{\mathrm{b}}$ and increase of $\mathrm{Al}_{\mathrm{c}}$, a value of $\mathrm{pH} 7.5$ can be roughly established as shown in Fig. 1B and C. This value corresponds well to the set point of precipitation of polymer species as reported in the study of Van Benschoten and Edzwald. Additional experiments have been carried out on the effect of coagulant dosages-the results (abbreviated) exhibit a similar trend to that observed here.

\subsection{Effect of aging}

After dosing into water, the speciation of coagulants undergoes complex transformation depending on the original composition and solution conditions as shown above. It is believed that the species formed immediately undergo structure rearrangement with aging. Further experiments were thus carried out to examine the effect of aging. The results obtained upon $1 \mathrm{~h}$ aging are shown in Figs. 2-6 as separate diagrams for clarity-AS, $\mathrm{PACl}_{0}, \mathrm{PACl}_{10}, \mathrm{PACl}_{20}$, and $\mathrm{PACl}_{25}$ respectively. The results of $2 \mathrm{~min}$ aging are also included for comparison. From these figures, it can be seen that there is significant change in speciation distribution with aging, depending on the $\mathrm{OH} / \mathrm{Al}$ ratio and the presence of sulfate ion. From Fig. 2, it can be seen that for alum the amount of $\mathrm{Al}_{\mathrm{a}}$ stays almost constant with aging. However, a significant decrease in $\mathrm{Al}_{\mathrm{b}}$ with a high yield of $\mathrm{Al}_{\mathrm{c}}$ occurs in the meantime. In the $\mathrm{pH}$ range of 4-4.5, a large proportion of $\mathrm{Al}_{\mathrm{b}}$ remains stable, while in the $\mathrm{pH}$ range of 4.5-5.5, a significance change of $\mathrm{Al}_{\mathrm{b}}$ to $\mathrm{Al}_{\mathrm{c}}$ takes place. The change becomes more rapid as $\mathrm{pH}$ is raised further above 6.5. The same effect of aging is observed for $\mathrm{PACl}_{0}$ except that the rapid change of $\mathrm{Al}_{\mathrm{b}}$ to $\mathrm{Al}_{\mathrm{c}}$ occurs at higher $\mathrm{pH}$. This again indicates the strong effect of the sulfate ion. The kinetics for polymer aggregation and precipitation are markedly accelerated in the presence of sulfate. For PACls at higher $\mathrm{OH} / \mathrm{Al}$ ratio, the same trend can be observed, but it becomes gradually less observable with increasing $\mathrm{OH} / \mathrm{Al}$ ratio. For $\mathrm{PACl}_{25}$, the effect of aging is very small. The change of $\mathrm{Al}_{\mathrm{b}}$ to $\mathrm{Al}_{\mathrm{c}}$ occurs relatively slowly.

The results shown above indicate that the effect of aging on PACls is largely dependent on solution conditions. For alum and $\mathrm{PACl}_{0}$, in the two $\mathrm{pH}$ limits examined, (i.e. $\mathrm{pH}$ 4 and 10), the species remains mainly as $\mathrm{Al}_{\mathrm{a}}$, which shows little change with aging. However, an increase in the $\mathrm{Al}_{\mathrm{a}}$ fraction with aging can be observed for PACls at higher $\mathrm{OH} / \mathrm{Al}$ ratio. This indicates that in the presence of free $\mathrm{H}^{+}$ (low $\mathrm{pH}$ ) or free $\mathrm{OH}^{-}$(high $\mathrm{pH}$ ), dissolution of the polymer species occurs during aging. In the $\mathrm{pH}$ range $4.0-4.5$, the $A l_{b}$ fraction formed is relatively stable with aging. A rough estimate of the relevant $\mathrm{OH} / \mathrm{Al}$ ratio is the range of $0.5-2.5$ for alum and $\mathrm{PACl}_{0}$. This illustrates that a fraction of stable polymer species could also be formed under this solution 

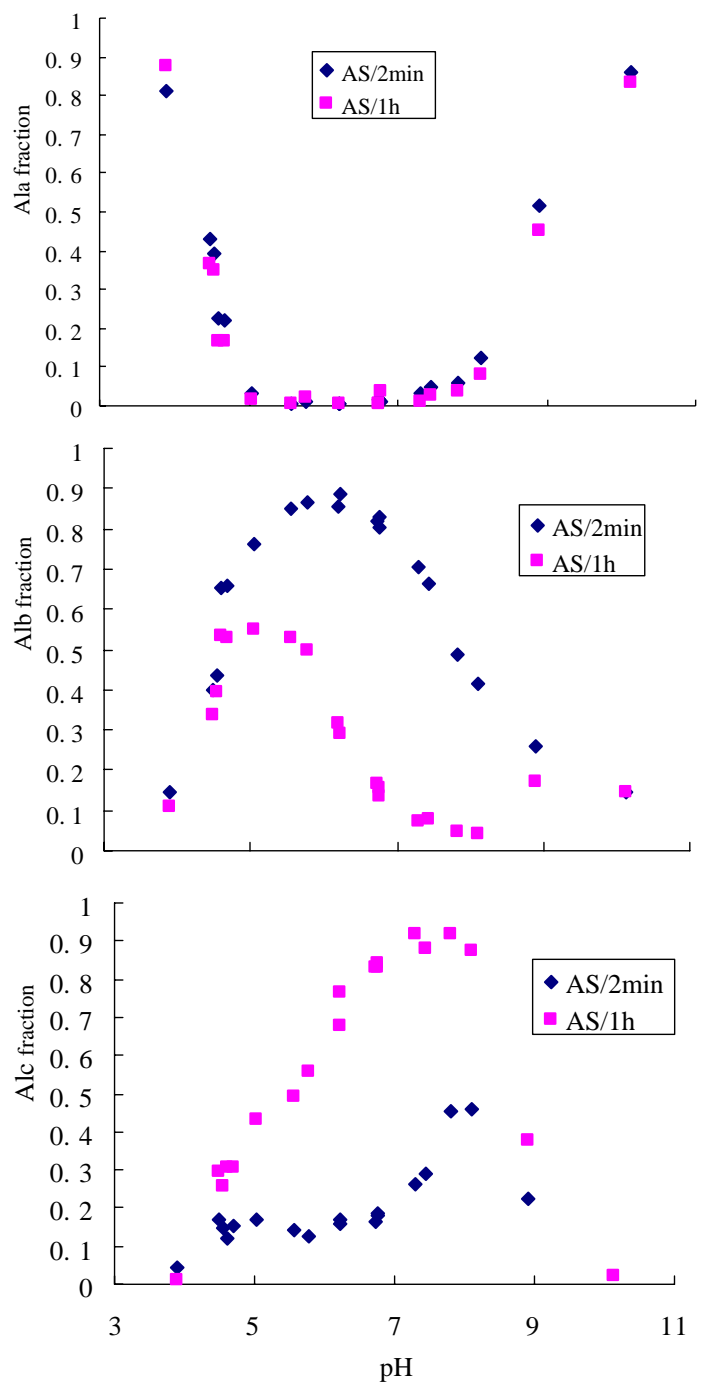

Fig. 2. The effect of aging on speciation distribution after dosing for alum (the same condition as in Fig. 1). (For interpretation of the references to color in this figure legend, the reader is referred to the web version of the article.)

condition. Increasing $\mathrm{pH}$ to the range of 5.5-6.5 means that the $\mathrm{OH} / \mathrm{Al}$ ratio is raised to $2.5-3.0$ for alum and $\mathrm{PACl}_{0}$, which results in a rapid aggregation of the polymer species. Upon further increase of the solution $\mathrm{pH}$, flocculation occurs, promoting particle aggregation and formation of amorphous hydroxide precipitates. In the presence of the sulfate ion, precipitation is accelerated at lower $\mathrm{pH}$.

Furthermore, there is a significant difference between the stability of the pre-formed $\mathrm{Al}_{\mathrm{b}}$ species and that formed in-situ after dosing. As shown above, although the maximum of $\mathrm{Al}_{\mathrm{b}}$ is formed in the near neutral $\mathrm{pH}$ range for alum and low $\mathrm{OH} / \mathrm{Al}$ ratio PACls, upon short aging this species undergoes rapid transform into $\mathrm{Al}_{c}$. The preformed $\mathrm{Al}_{\mathrm{b}}$ remains relatively stable throughout the $\mathrm{pH}$ range. The difference in stability of preformed $\mathrm{Al}_{\mathrm{b}}$ to that formed in situ after dosing is indicative of a structural difference between them. This
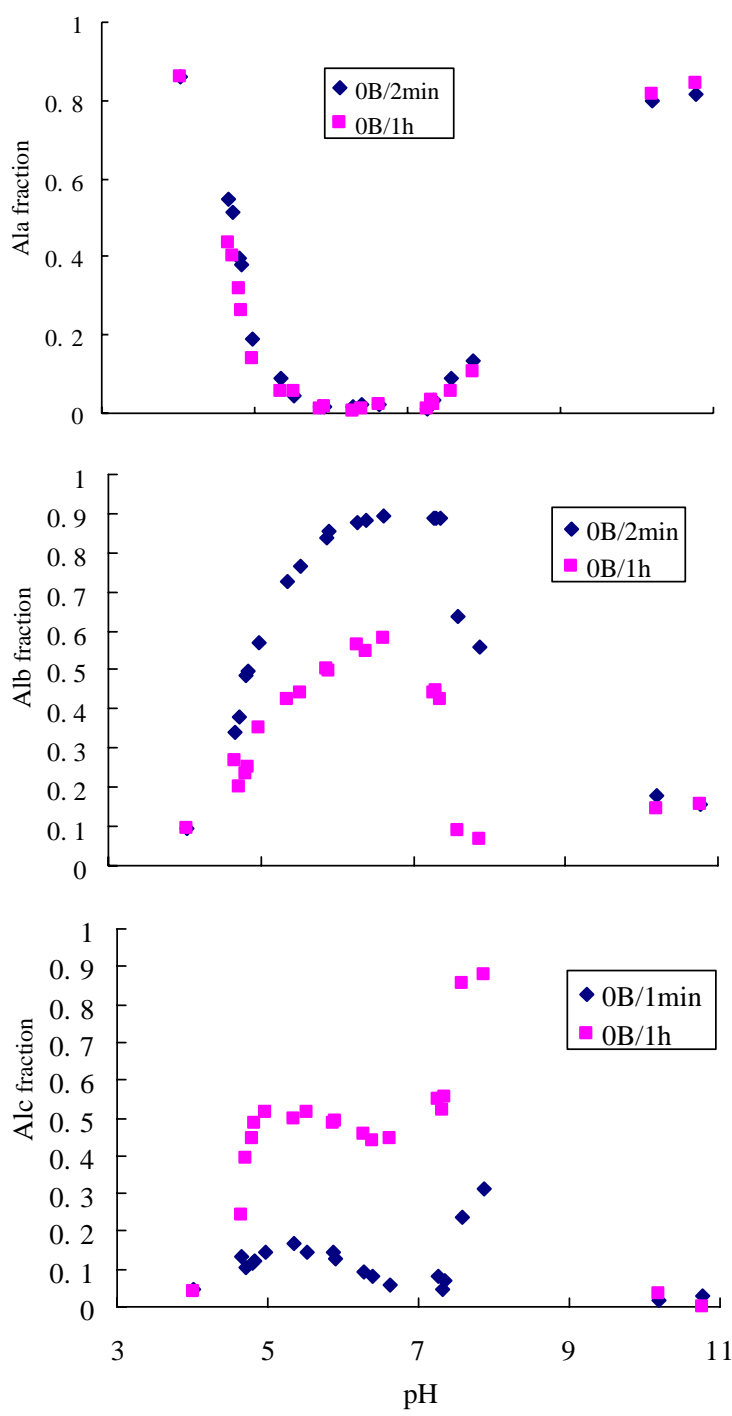

Fig. 3. The effect of aging on speciation distribution after dosing for $\mathrm{PACl}_{0}$ (the same condition as in Fig. 1). (For interpretation of the references to color in this figure legend, the reader is referred to the web version of the article.)

may be due to the likely different reaction pathways for the formation of these $\mathrm{Al}_{\mathrm{b}}$ species.

\subsection{General discussion}

A review of aluminum hydrolysis chemistry reveals that two main kinds of mechanism for hydrolysis-polymerization exist. The most popular is the "core-link" or hexameric ring scheme, in addition to the more recent model of polynuclear formation involving a typical species of tridecameric, $\mathrm{Al}_{13} \mathrm{O}_{4}(\mathrm{OH})_{24}{ }^{7+}$ (also reported to range from $3+$ to $7+$, normally simplified as $\mathrm{Al}_{13}$ ). The basic unit of the first model for aluminum polynuclear formation is either the $\left[\mathrm{Al}_{6}(\mathrm{OH})_{12}\left(\mathrm{H}_{2} \mathrm{O}\right)_{12}\right]^{6+}$ (single ring) or the $\mathrm{Al}_{10}(\mathrm{OH})_{22}\left(\mathrm{H}_{2} \mathrm{O}\right)_{16}{ }^{8+}$ (double ring) species [29]. The main feature of this mode is that the hydrolysis species may be 

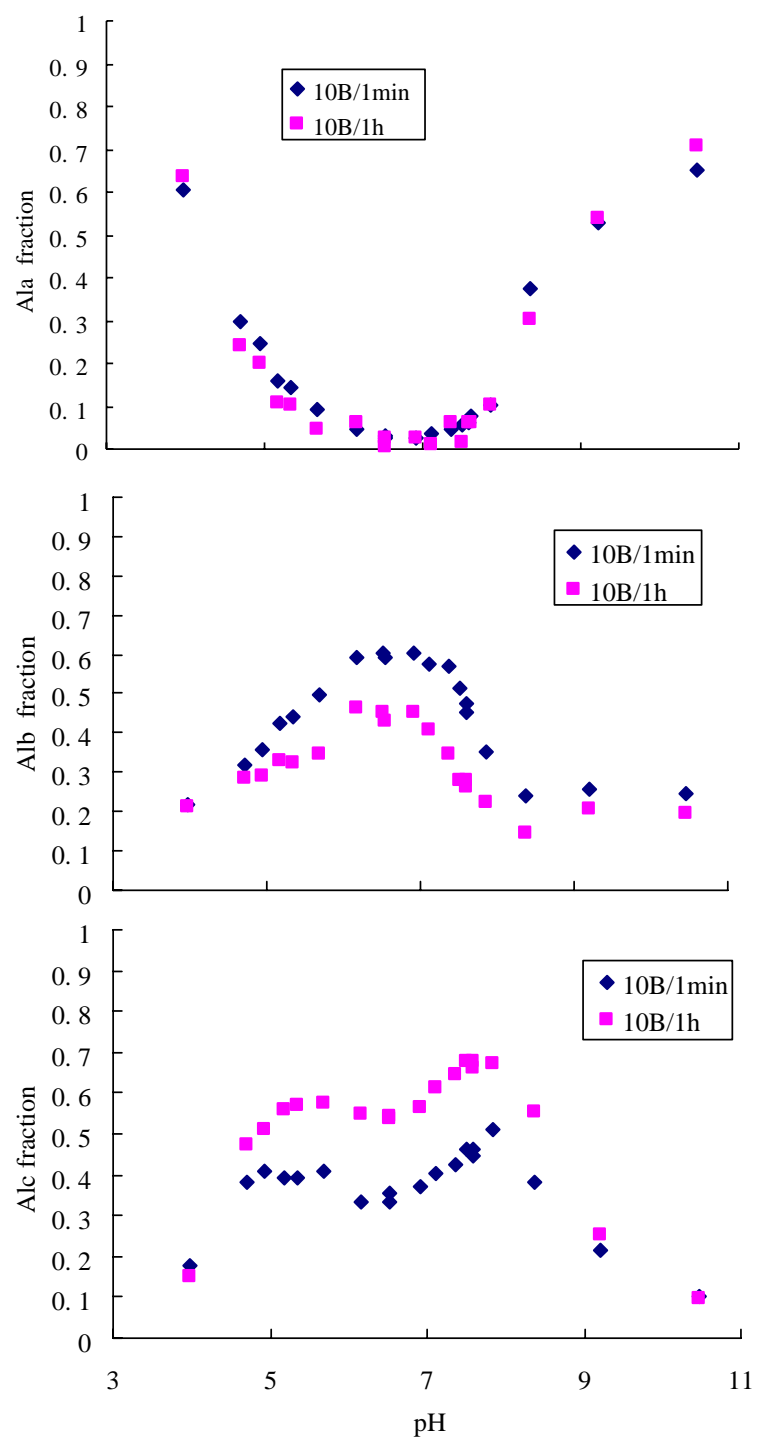

Fig. 4. The effect of aging on speciation distribution after dosing for $\mathrm{PACl}_{10}$ (the same condition as in Fig. 1). (For interpretation of the references to color in this figure legend, the reader is referred to the web version of the article.)

continuously formed from monomer to polymer by bidimensional growth of the hexameric ring units. Therefore, many possible polynuclear species can be formed. The principal species will then depend mainly on the experimental conditions. In essence, the basic hexameric ring or "core-link" model was originally proposed as a logical extension of the solid state, crystalline aluminum trihydroxide structure. Although there is no direct verification of all of the possible structures, the model gains quite popular approval especially among the area of geochemistry and soil chemistry, since the resulting polymers prefigure the crystal structure of the aluminum trihydroxide polymorphs, gibbsite, bayerite, and nordstrandite. It is therefore possible to write the schematic reaction pathways from polymerization towards precipitation as Oct-Path 1:
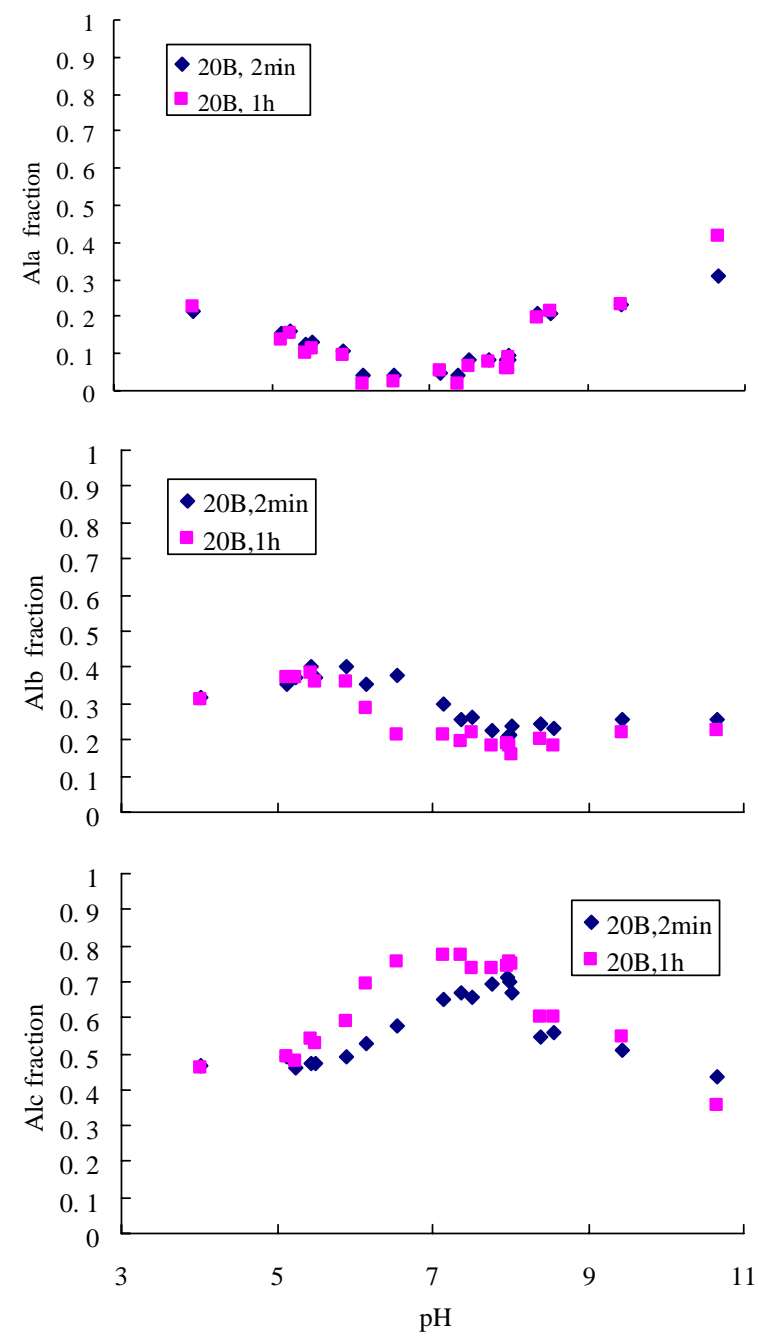

Fig. 5. The effect of aging on speciation distribution after dosing for $\mathrm{PACl}_{20}$ (the same condition as in Fig. 1). (For interpretation of the references to color in this figure legend, the reader is referred to the web version of the article.)

$$
\begin{aligned}
\mathrm{Al}(\mathrm{OH})_{i}{ }^{3-i} & \Leftrightarrow \mathrm{Al}_{2}(\mathrm{OH})_{m}{ }^{6-m} \Leftrightarrow \mathrm{Al}_{6}(\mathrm{OH})_{n}{ }^{18-n} \\
& \Leftrightarrow \ldots \Leftrightarrow\left(\mathrm{Al}_{\mathrm{Oct}}\right)_{x}{ }^{n+}(\text { agg. }) \\
& \Leftrightarrow \mathrm{Al}(\mathrm{OH})_{3}(\mathrm{~s}) \quad \text { Path } 1
\end{aligned}
$$

More recently, based on the direct measurement by ${ }^{27} \mathrm{Al}$ NMR and small angle X-ray diffraction, the polynuclear formation model was proposed. It is postulated that only several possible species in solution and direct transformation among them exist, such as monomers, dimers, tridecamer $\left(\mathrm{Al}_{13}\right)$, and aggregates. The existence of a tridecamer with a so-called Keggin structure has been verified by several investigators [30-32]. This species forms rapidly and irreversibly when $\mathrm{Al}(\mathrm{OH})_{4}{ }^{-}$interacts with 12 octahedrally coordinated aluminum ions, and does not form on aging via polymer intermediates as suggested by Baes and Mesmer [30]. Akitt and Farthing proposed a mechanism of $\mathrm{Al}_{13}$ polynuclear formation whereby six dimeric species nucleate around $\mathrm{Al}(\mathrm{OH})_{4}{ }^{-}$[33]. However, several uncertainties 

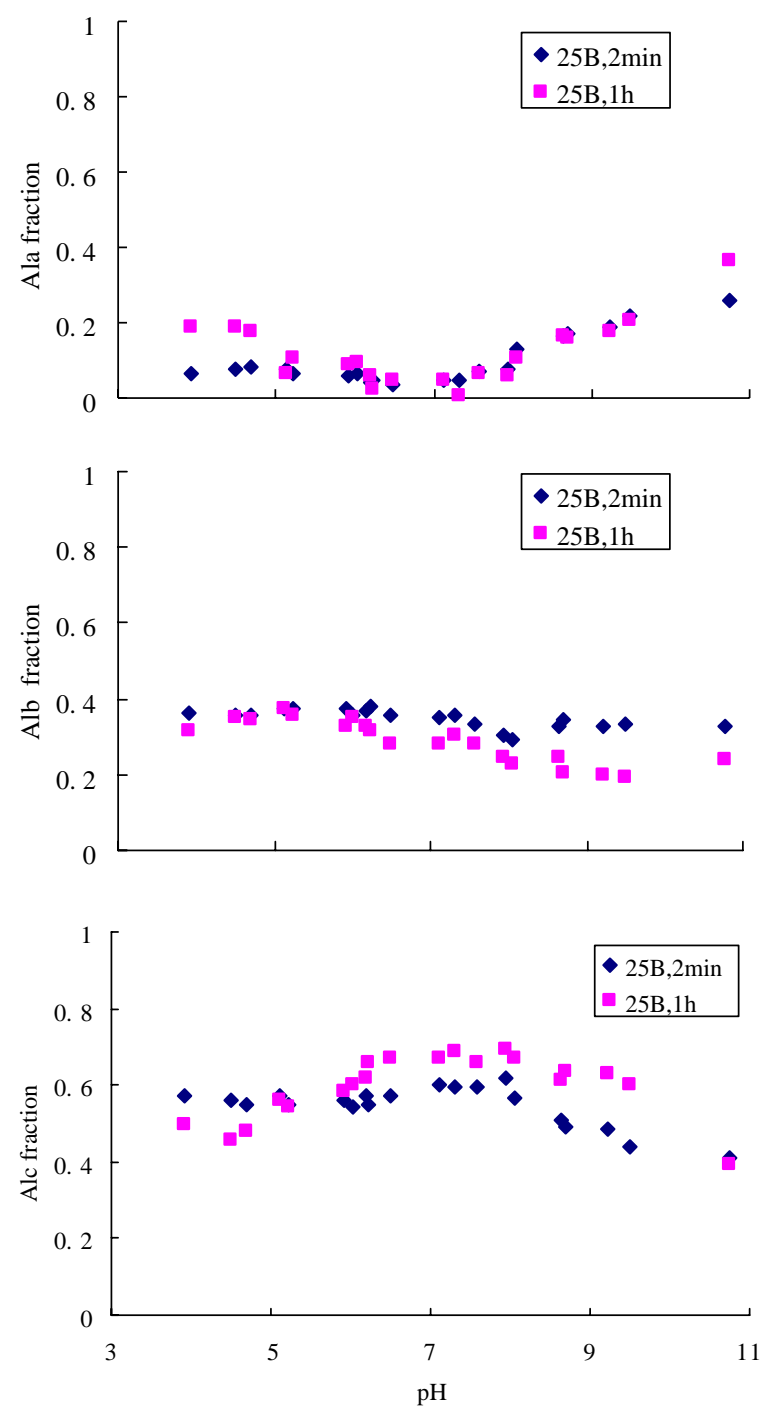

Fig. 6. The effect of aging on speciation distribution after dosing for $\mathrm{PACl}_{25}$ (the same condition as in Fig. 1). (For interpretation of the references to color in this figure legend, the reader is referred to the web version of the article.)

remain in this model. It can not explain the entire process of species formation, distribution and transformation. There are some species beside the total aluminum concentration that can not be detected using the ${ }^{27} \mathrm{Al}$ NMR technique. And the mechanism for further transformation of $\mathrm{Al}_{13}$ structure to aluminum trihydroxide is still to be confirmed, though some progress has been made in this regard [34,35]. Regardless, based on the direct instrument detection, the $\mathrm{Al}_{13}$ model has gained more and more approval. The possible schematic reaction pathways from polymerization towards precipitation involving $\mathrm{Al}_{13}$ might be written as Tetra-Path 2:

$$
\begin{aligned}
& \frac{\mathrm{Al}(\mathrm{OH})_{i}{ }^{3-i}}{\mathrm{Al}_{2}(\mathrm{OH})_{m}{ }^{6-m}}+\mathrm{Al}(\mathrm{OH})_{4}{ }^{-} \Leftrightarrow \mathrm{Al}_{13} \Leftrightarrow\left(\mathrm{Al}_{13}\right)_{2} \\
& \Leftrightarrow\left(\mathrm{Al}_{13}\right)_{n} \Leftrightarrow\left(\mathrm{Al}_{13}\right)_{\text {aggr }} \quad \text { Path } 2
\end{aligned}
$$

It is therefore reasonable to infer a third pathway (Path 3) by mixing/combining Paths 1 and 2, with changes depending on the experimental conditions. For alum and $\mathrm{PACl}_{0}$ after dosing, Path 3 might occur resulting in $\mathrm{Al}_{\mathrm{b}}$ species of different structure around the wide $\mathrm{pH}$ range. For tailor-made PACls, the reaction scheme might follow Path 2 after dosing. However, the $\mathrm{Al}_{\mathrm{b}}$ fraction is formed in situ through Path 3 , in the main contribution from the $\mathrm{Al}_{\mathrm{a}}$ fraction in the original composition, as addressed previously. Upon aging, a structure rearrangement occurs rapidly through transformation of the hydroxy-bridge to an oxo-bridge:

$-\mathrm{Al}\left(\begin{array}{c}\mathrm{OH} \\ \mathrm{OH}\end{array}\right) \mathrm{Al}-\Leftrightarrow-\mathrm{Al}-\mathrm{O}-\mathrm{Al}-+\mathrm{H}_{2} \mathrm{O}$

While such an aging effect might occur spontaneously on the adjacent bridge points among aggregated polymers and polymer species, the shape and size of the structure undergo some consequent changes. The reactivity of species with ferron evidently slows with aging. Bottero et al. [35] observed more dense and less open clusters formed extremely rapidly at the onset of precipitation $(\mathrm{OH} / \mathrm{Al}=2.6)$, protecting the structure components from hydrolysis. Upon aging, the clusters were smaller but their density remained approximately the same. The authors considered that octahedral hydroxyls belonging to adjacent units may condense into oxo-bridges. Al tetrahedral with perturbed symmetry was compacted between growing octahedral layers, and remained protected against the hydrolysis induced by $\mathrm{OH}^{-}$.

The information provided by the ferron method is mainly based on the reactivity of species with ferron reagent, as indicated by the kinetic difference of absorbance over time scales of $2 \mathrm{~h}$. It becomes difficult to distinguish the possible differences in structure among the species exhibiting a similar reactivity with ferron. As shown previously, the $\mathrm{PACl}_{25}$ after dosing shows relatively constant reactivity with ferron throughout the $\mathrm{pH}$ range investigated. It is known that the polymer species become aggregated and precipitate out above $\mathrm{pH} 7.5$ [11]. Therefore, a detailed examination of the kinetic aspects of ferron assay in combination with particle size information would give much insight into species formed in situ after dosing.

In conclusion, the speciation transformation of coagulants after dosing depends to a large extent on primary composition, and the solution chemical conditions such as coexisting anions, $\mathrm{OH} / \mathrm{Al}$ ratio, and $\mathrm{pH}$. $\mathrm{PACls}$ with high $\mathrm{OH} / \mathrm{Al}$ ratio exhibit quite stable speciation and tend to maintain original composition under the various conditions.

\section{Acknowledgements}

The kind comments by the anonymous reviewers are greatly appreciated. This work is supported by the NSF of China 50078051 and 20277042. 


\section{References}

[1] H.X. Tang, W. Stumm, The coagulation behavior of Fe(III) polymeric species-I, II, Water Res. 21 (1) (1987) 115-123.

[2] H.X. Tang, Basic studies of inorganic polymer flocculants, Environ. Chem. 9 (3) (1990) 1-12 (in Chinese).

[3] D.S. Wang, H.X. Tang, J. Gregory, Relative importance of chargeneutralization and precipitation during coagulation with IPF-PACl: effect of sulfate, Environ. Sci. Technol. 36 (8) (2002) 3866.

[4] I.M. Solomentseva, N.G. Gerasimenko, S. Barany, Colloids Surf. 151 (1999) 113-126.

[5] Y. Matsui, A. Yuasa, Y. Furuya, T. Kamei, J. Am. Water Wks Assn. 88 (10) (1996) 96-106.

[6] H.X. Tang, B.Z. Tian, Z.K. Luan, Y. Zhang, PFCl, in: R. Klute, H.H. Hahn (Eds.), Chemical Water and Wastewater Treatment (III), Springer-Verlag, 1994, pp. 57-69.

[7] H.X. Tang, Z.K. Luan, D.S. Wang, B.Y. Gao, Compsite inorganic polymer flocculant, in H.H. Hahn, et al. (Eds.), Chemical Water and Wastewater Treatment (V), Springer-Verlag, 1998, pp. 24 33.

[8] D.S. Wang, H.X. Tang, Modified inorganic polymer flocculant-PFSi: its preparation, characterization and coagulation behavior, Water Res. 35 (14) (2001) 3418-3428.

[9] K. A Gray, C.H. Yao, C.R. O’Melia, J. Am. Water Wks Assn. 87 (4) (1995) 136.

[10] H.X. Tang, Z.K. Luan, the different behavior and mechanism between inorganic polymer f locculant and traditional coagulants, in: H.H. Hahn, et al. (Eds.), Chemical Water and Wastewater Treatment (IV), Springer-Verlag, 1996, pp. 83-93.

[11] J. Van Benschoten, J.K. Edzwald, Water Res. 24 (12) (1990) 1519.

[12] P.M. Bertsch, D.R. Parker, Aqueous polynuclear aluminum species, in: G. Sposito (Ed.), The Environmental Chemistry of Aluminum, CRC Press, 1996, pp. 87-115.

[13] M.A. Blesa, E. Matijevic, Phase transformations of iron oxides, oxohydroxides, and hydrous oxides in aqueous media, Adv. Colloid Interface Sci. 29 (1989) 173-221.

[14] R.M. Cornell, R. Giovdnoli, W. Schneider, Review of the hydrolysis of iron(III) and the crystallization of amorphous iron(III) hydroxide hydydrate, J. Chem. Tech. Biotechnol. 46 (1989) 115-134.

[15] M.C. Flynn, The hydrolysis of inorganic iron(III) salts, Chem. Rev. 84 (1984) 31-41.

[16] R.W. Smith, Reactions among equilibrium and nonequilibrium aqueous species of aluminum hydroxy complexes, Adv. Chem. Ser. 106 (1971) 250.

[17] R.W. Smith, J.D. Hem, Effect of aging on aluminum hydroxide complexes in dilute solutions, U.S. Geol. Surv. Water Supply Paper, 1827-D, 1972.
[18] P.M. Jardine, L.W. Zelazny, Mononuclear and polynuclear aluminum speciation through differential kinetic reactions with ferron, Soil Sci. Soc. Am. J. 50 (1986) 895.

[19] P.H. Hsu, D. Cao, Effects of acidity and hydroxylamine on the determination of aluminum with ferron, Soil Sci. 152 (3) (1990) 210-219.

[20] K.A. Gray, The preparation, characterization and use of inorganic iron(III) polymers for coagulation in water treatment, doctoral dissertation, The Johns Hopkins University, Baltimore, MD, 1988.

[21] D.R. Parker, P.M. Bertsch, Identification and quantification of the $\mathrm{Al}_{13}$ tridecameric polycation using ferron, Environ. Sci. Technol. 26 (1992) 908.

[22] S.J. Duffy, G.W. vanLoon, Environ. Sci. Technol. 28 (1994) 19501956.

[23] A. Amirtharajah, K.J. Mills, JAWWA 74 (4) (1982) 210.

[24] P.N. Johnson, A. Amirtharajah, JAWWA 75 (5) (1983) 232.

[25] R.D. Letterman, D.R. Iyer, Modeling the effects of hydrolyzed aluminum and solution chemistry on flocculation kinetics, Environ. Sci. Technol. 19 (1985) 673.

[26] P.L. Hayden, A.J. Rubin, Systematic investigation of the hydrolysis and precipitation of aluminum(III), in: A.J. Rubin (Ed.), Aqueous Environmental Chemistry of Metals, Ann Arbor Science, Ann Arbor, MI, 1976.

[27] S.S. Singh, The formation and coexisting of gibbsite, boehmite, alumina and alunite at room temperature, Can. J. Soil Sci. 62 (1982) 327.

[28] H. DeHek, R.J. Stol, P.L. DeBruyn, Hydrolysis-precipitation studies of aluminum(III) solutions. III. The role of sulfate ion, J. Colloid Interface Sci. 64 (1978) 72.

[29] P.H. Hsu, Aluminum hydroxides and oxyhydroxides, in: J.B. Dixon, S.W. Weed (Eds.), Minerals in Soil Environments, Madison, WI 1989, pp. 331-378.

[30] C.F. Baes, R.E. Mesmer, The Hydrolysis of Cations, Wiley, NY, 1976.

[31] M.V. Rausch, H.D. Bale, Small-angle X-ray scattering from hydrolyzed Al nitrate solutions, J. Chem. Phys. 40 (1964) 3391.

[32] J. Aveston, Hydrolysis of aluminum ion: ultracentrifugation and acidity measurements, J. Chem. Soc. (1965) 4438.

[33] J.W. Akitt, A. Farthing, Aluminum-27 nuclear magnetic resonance studies of the hydrolysis of aluminum(III). IV. Hydrolysis using sodium carbonate, J. Chem. Soc., Dalton Trans. (1981) 1617.

[34] S.M. Bradley, R.A. Kydd, R. Yamdagni, Comparison of the hydrolysis of gallium(III) and aluminum(III) solutions by nuclear magnetic resonance spectroscopy, J. Chem. Soc., Dalton Trans. (1990) 2653.

[35] J.Y. Bottero, M. Axelos, D. Tchoubar, J.M. Cases, J.J. Fripiat, F Fiessinger, Mechanism of formation of aluminum trihydroxide from Keggin $\mathrm{Al}_{13}$ polymers, J. Colloid Interface Sci. 117 (1987) 47. 